\title{
Milk progesterone levels in relation to conception, repeat breeding and factors influencing acyclicity in dairy cows
}

\author{
D. Claire Bulman and G. E. Lamming \\ Department of Physiology and Environmental Studies, University of Nottingham, School of Agriculture, \\ Sutton Bonington, Nr Loughborough, Leicestershire, U.K.
}

\begin{abstract}
Summary. Milk samples were collected twice weekly from 535 dairy cows between parturition and the re-establishment of pregnancy to monitor ovarian activity by measurement of milk progesterone levels by radioimmunoassay. The mean progesterone levels after fertile and non-fertile first inseminations were similar from 21 days before until 13 days after insemination, those in non-pregnant animals declined while those in pregnant animals continued to rise until Day 22. Progesterone profiles of 47 repeat breeder cows (i.e. receiving $>3$ inseminations) demonstrated that a variety of patterns was associated with the poor conception rate.

A study of the post-partum interval showed that cows resumed cycles by $24 \pm 0.6$ days after calving; the length of this interval varied significantly with the season of calving and non-significantly with the lactation number (i.e. age) of the cow, but was not related to yield. Of the 535 cows studied, $5 \cdot 2 \%$ had not started to cycle within 50 days of calving and a further $5 \cdot 2 \%$ resumed cycles which subsequently ceased. The progesterone profiles of acyclic cows indicated that after treatment with $0.5 \mathrm{mg} \mathrm{LH}-\mathrm{RH}$ or a progesterone-releasing intravaginal device (PRID) for 14 days $75 \%$ of animals apparently ovulated but the calving to conception interval was not significantly altered compared with that of untreated control cows.
\end{abstract}

\section{Introduction}

Reproductive performance is one of the important factors determining the profitability of dairy herds. Ideally the calving interval should average 1 year (Louca \& Legates, 1968) but this can only be achieved if the rates of conception and detection of oestrus are high and the interval between parturition and first service is less than 90 days (Esslemont \& Ellis, 1975; Pelissier, 1976). The majority of dairy cows resume ovarian cycles within the first month after parturition (Callahan, Erb, Surve \& Randel, 1971; King, Hurnik \& Robertson, 1976). Some animals have a longer post-partum interval and may still be acyclic during the period when they should be inseminated (Lamming \& Bulman, 1976).

The endocrine changes which normally accompany oestrus and ovulation in the cow have often been studied (see Hansel, Concannon \& Lukaszewska, 1973; Schams, Schallenberger, Hoffmann \& Karg, 1977), and Erb, Garverick, Randel, Brown \& Callahan, (1976) found that infertile inseminations were often accompanied by asynchronies in the hormonal profile. Casida (1961) suggested that repeat breeding could be caused by an inadequate supply of progesterone and Rosenberg, Herz, Davidson \& Folman (1977) reported that lower conception rates during the summer months in Israel were accompanied by significantly lower progesterone concentrations during the luteal phase of the cycle.

Milk progesterone analysis offers a convenient method of monitoring ovarian activity in a large number of dairy cows so that abnormal patterns of progesterone secretion can be studied (Lamming \& Bulman, 1976). We have used this technique for the present studies of (1) the relationship between the pattern of progesterone secretion and the likelihood of conception, with an analysis of the progesterone profiles of cows classified as repeat breeders, and (2) the identification, incidence and treatment of anoestrous lactating cows, with an analysis of the relationship between the incidence of acyclicity and age, season and milk yield. 


\section{Materials and General Methods}

Milk samples were collected twice weekly from 535 lactating Friesian or Ayrshire dairy cows (280 May 1976-April 1977 and 255 May 1977-December 1977) in 4 commercial dairy herds, commencing within 2 weeks of parturition and continuing until each animal was diagnosed pregnant by an elevated milk progesterone level 24 days after service. The progesterone profiles of each cow were collated with the records of oestrus and insemination. The animals were generally inseminated at the first oestrus occurring after 55 days post partum. On 3 farms all the cows were inseminated artificially while natural service was used for selected cows only on the 4 th farm.

Progesterone assay. The radioimmunoassay used was developed from that of Gadsby, Heap, Henville \& Laing (1974) and has been described by Bulman \& Lamming (1976) and Lamming \& Bulman (1976). The antiserum used was BF465 no. 6 (Furr, 1973): and the cross-reactions of $>5 \%$ were $74 \%$ against $11 \alpha$-hydroxypregnen-4-ene-3,20-dione, $41 \%$ against $5 \alpha$-pregnane-3,17-dione, $10 \%$ against $5 \beta$-pregnane-3,17-dione, and $7 \%$ against $11 \beta$-hydroxypregnen-4-ene-3,20-dione. The levels of these steroids in milk are known to be low and unlikely to affect the assay (Darling \& Harkness, 1973, Darling, Laing \& Harkness, 1974). The progesterone values measured were $9.55 \pm 0.4$ (s.e.m.), $15.67 \pm 0.7$ and $24.45 \pm 0.8 \mathrm{ng} / \mathrm{ml}$ when 5,10 and $20 \mathrm{ng}$ progesterone $/ \mathrm{ml}$ respectively were added ( $n=10$ for each) to milk containing $4.68 \mathrm{ng}$ progesterone $/ \mathrm{ml}$. The intra-assay coefficient of variation between duplicate pairs of samples was $8.9 \%$ and the inter-assay coefficient of variation was $10.3 \%$. The limit of sensitivity, defined as twice the s.d. of the blank values, was $0.38 \mathrm{ng} / \mathrm{ml}$ (10 assays). There was a highly significant correlation $(r=0.75, n=100, P<0.01)$ between the progesterone concentrations in plasma and milk samples collected at the time same (Lamming \& Bulman, 1976).

Statistical analysis. Statistical comparisons were performed by analysis of variance or Generalised Linear Interactive Modelling (GLIM) which uses a log linear model and Poisson errors (Nelder \& Wedderburn, 1972; Nelder, 1974).

\section{Study 1}

\section{Progesterone levels and conception}

Of the 535 cows examined, $350(65.5 \%)$ conceived to the first service; 47 of the remaining 185 cows had not conceived after 3 services and were considered to be repeat breeders. Excluding those cows which had received progesterone treatment (see Study 2), the milk progesterone profiles of about 160 of the cows conceiving to first service (Group P) and 160 (i.e. including some of the 47 repeat breeders) of those returning to first service (Group $R$ ) were examined to see whether the progesterone levels before and after first insemination differed between cows which did or did not conceive. The day of insemination was taken as Day 0 and the daily milk progesterone concentrations from 21 days before until 24 days after the first insemination for the two groups were compared (Text-fig. 1).

The mean progesterone values for the two groups of cows were similar until Day 13 when the concentrations in the non-pregnant animals declined whereas those in the pregnant cows continued to increase. The pattern of this increase over time is probably some asymptotic function but the choice of function has been left until data extending further into pregnancy have been collected and analysed. Therefore as a first approximation only a quadratic equation $(y=4 \cdot 84+2 \cdot 40 t-$ $0.547 t^{2}$, where $t=$ days) was fitted for the values from Days 3 to 24 . There was clear evidence that the variability increased with the mean and this will have to be taken into account in further analyses when more data are collected later in pregnancy.

Analysis of variance was used to compare the slopes obtained from the values for Groups $\mathbf{P}$ and $\mathbf{R}$ during the early luteal phases before and after conception (Days -18 to -9 and Days 3 to 12 , see Text-fig. 1): the slopes were all within the range 1.25-1.60 and the parameters defining the lines did not differ significantly. Student's $t$ test was used to compare the progesterone values for the 2 groups on each day between Days -21 and +12 . Significant differences were found on some days $(-16,-13$, $-6,+1,+11)$, but they were in opposite directions with no consistent trend. The range of progesterone values on each day indicated that low concentrations in $_{f}$ milk $_{1}$ in $_{C}$ individual $_{0}$ cows between Days $s_{10 A M}$ 
-10 to +10 could be consistent with conception. Progesterone levels of $<1 \mathrm{ng} / \mathrm{ml}$ were recorded in individual cows of Group P on Day -9 , Days -7 to +5 inclusive and on Day +7 ; on each of the other days during this period at least one cow had a value of $<6 \mathrm{ng} / \mathrm{ml}$.

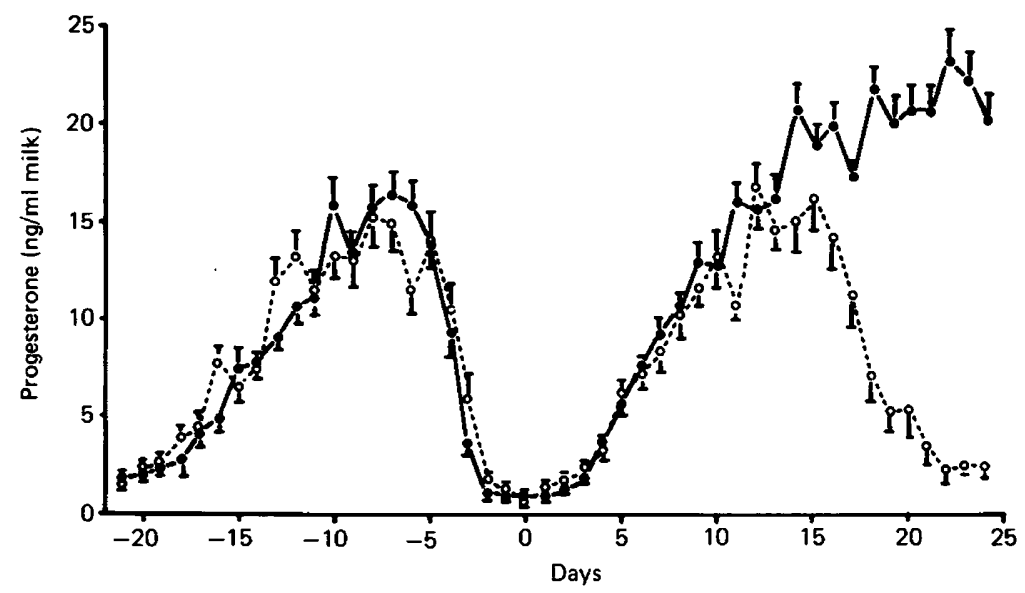

Text-fig. 1. Milk progesterone levels before and after the first insemination (Day 0 ) after calving in cows which did $(\bullet)$ or did not $(O)$ conceive to that insemination. There were about 160 cows in each group but each point is the mean \pm s.e.m. of 40 observations.

This point is further emphasized by the data shown in Text-fig. 2 for 2 cows, one with low milk progesterone levels during the 9 days before insemination and the other with low concentrations for 11 days after insemination. Both cows conceived and calved to that service.

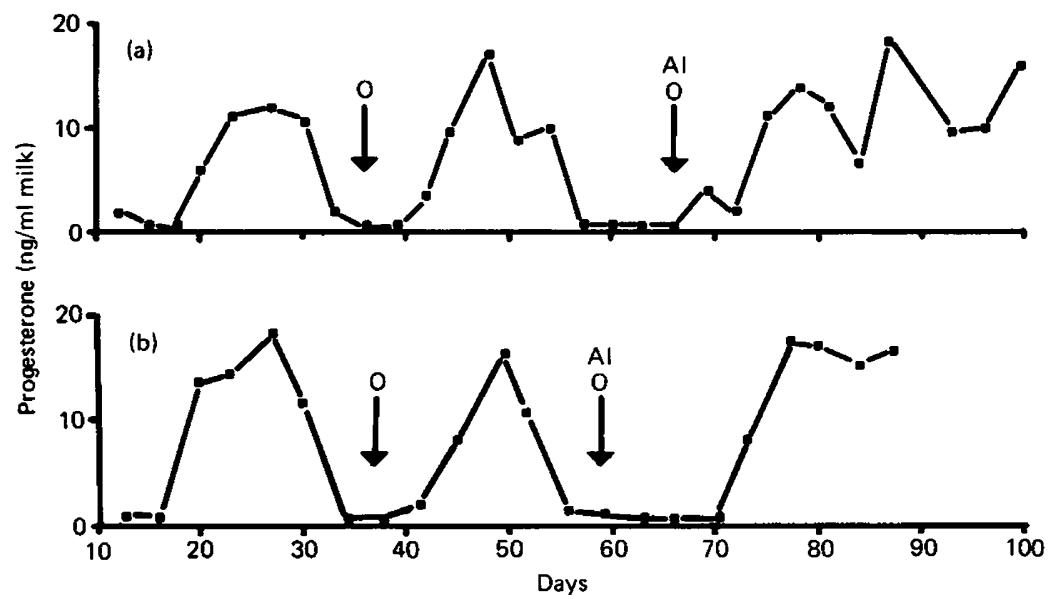

Text-fig. 2. Progesterone profiles of two cows which conceived although insemination was preceded (a) or followed (b) by a longer than usual period with low progesterone concentrations. $\mathrm{O}=$ oestrus; $\mathrm{AI}=$ artificial insemination.

It was therefore clear that failures to conceive could not generally be attributed to differences in the milk progesterone secretion pattern. However, profiles of individual cows suggested that irregularities in the progesterone profiles of some animals were associated with a low conception rate and this aspect was investigated further. 


\section{Progesterone levels and repeat breeding}

The progesterone profiles of the 47 repeat breeders were examined to investigate the reasons for their poor conception rate. On the basis of the progesterone profiles they were categorized as shown in Table 1 and are exemplified in Text-fig. 3. A 'normal' profile was considered to be one in which the luteal phase with progesterone levels $>10 \mathrm{ng} / \mathrm{ml}$ lasted for approximately 14 days: $30 \%$ of the cows had such a profile. Repeat breeding (categories III and IV) was associated with low or irregular progesterone profiles in $23 \%$ of the cows. The age distribution of the repeat-breeder cows was not significantly different from that of the population as a whole $\left(\chi^{2}{ }_{10}=10.57 ; P=0.3-0.5\right)$.

Table 1. A classification of the progesterone profiles of repeat breeder cows (i.e. those not conceiving at the first 3 services after calving) taken from a population of 535 animals

\begin{tabular}{|c|c|c|}
\hline Category of progesterone profile & No. of cows & $\begin{array}{c}\text { No. of cows } \\
\text { which eventually } \\
\text { conceived }\end{array}$ \\
\hline I Normal & 14 & 12 \\
\hline $\begin{array}{l}\text { II Prolonged luteal activity for }>30 \text { days in a cow which had not been } \\
\text { inseminated }\end{array}$ & 3 & 2 \\
\hline III Erratic & 5 & 4 \\
\hline IV Ovarian cycles ceased for a period $>14$ days & 6 & 5 \\
\hline V Insemination given during luteal phase of the cycle & 4 & 3 \\
\hline $\begin{array}{l}\text { VI Insemination given to apparently pregnant cow followed by embryonic } \\
\text { mortality }\end{array}$ & 5 & 5 \\
\hline $\begin{array}{l}\text { VII Embryonic mortality indicated by a decline in progesterone concen- } \\
\text { tration to baseline after elevation for }>30 \text { days following insemination }\end{array}$ & 10 & 6 \\
\hline Total & 47 & 37 \\
\hline
\end{tabular}

Service interval. The service intervals for the cows with normal profiles (Category I) were generally 19-25 days: 3 of the 14 cows had at least one interval of 26-29 days but in none was the interval shorter than 14 days. In all the categories an undetected oestrus resulted in longer intervals of 36-47 days ( 1 oestrous period not observed) or 56-69 days ( 2 consecutive oestrous periods not observed). Long intervals (31-59 days) were also characteristic of the cows in Category VII (embryonic mortality). Short service intervals of $<18$ days occurred in Categories II, III, IV, V and VI. For cows which were inseminated in mid cycle (Category V) service intervals of 8-12 days were recorded. Animals in Category VI received 2 inseminations about 3 weeks apart although the progesterone concentration was still high at the time of the second insemination, luteolysis then occurred and the cows became oestrous again 10-16 days after the second unnecessary insemination. Those animals in Categories II, III and IV which received 2 inseminations at short intervals (4-17 days) generally had no apparent luteal development between services. In two cows (Category III) short luteal phases were recorded resulting in service intervals of 15 and 16 days respectively.

Conception rate. Of the 47 repeat breeder cows 26 conceived after 4 inseminations, 9 after 5 , and 2 after $6 ; 10$ cows received $4-7$ inseminations without conceiving and were then sold. Five of the normal animals (Category I) were studied again during their subsequent lactation and 2 conceived after 1 insemination, 2 after 2 and the fifth was sold after 3 inseminations had not resulted in conception.

\section{Study 2}

The progesterone profiles from all 535 animals were examined and the interval between parturition and the resumption of ovarian activity was measured. Ovarian activity was identified as the first progesterone measurement $>3 \mathrm{ng} / \mathrm{ml}$ which was followed by ovarian cycles. The cows which were characterized by persistently low progesterone levels were distinguished as follows: Group :A, $10 \mathrm{AM}$ 
animals which had not resumed cyclic ovarian activity within 50 days of parturition (19 in Year 1 and 9 in Year 2), and Group B, animals in which ovarian cycles started but then ceased for a period exceeding 14 days (16 in Year 1 and 12 in Year 2). This classification was made independently of that used in Study 1. The cows in Groups A and B were randomly assigned to one of three treatment groups: (i) no treatment (controls); (ii) a single intramuscular injection of $0.5 \mathrm{mg} \mathrm{LH}-\mathrm{RH}$ (Hoe 470 : Hoechst) in $10 \mathrm{ml} \mathrm{0.154} \mathrm{M}-\mathrm{NaCl}$; (iii) insertion of a progesterone-releasing intravaginal device (PRID: Abbott Laboratories Ltd) for 14 days but no oestrogen treatment. Ovarian cycles have been induced in cows with ovarian cysts or during post-partum anoestrous by treatment with progesterone (Johnson \& Ulberg, 1967; Gonzallez-Padilla, Wiltbank \& Niswender, 1975) or LH-RH (Kittok, Britt \& Convey, 1973, Bierschwal et al., 1975).
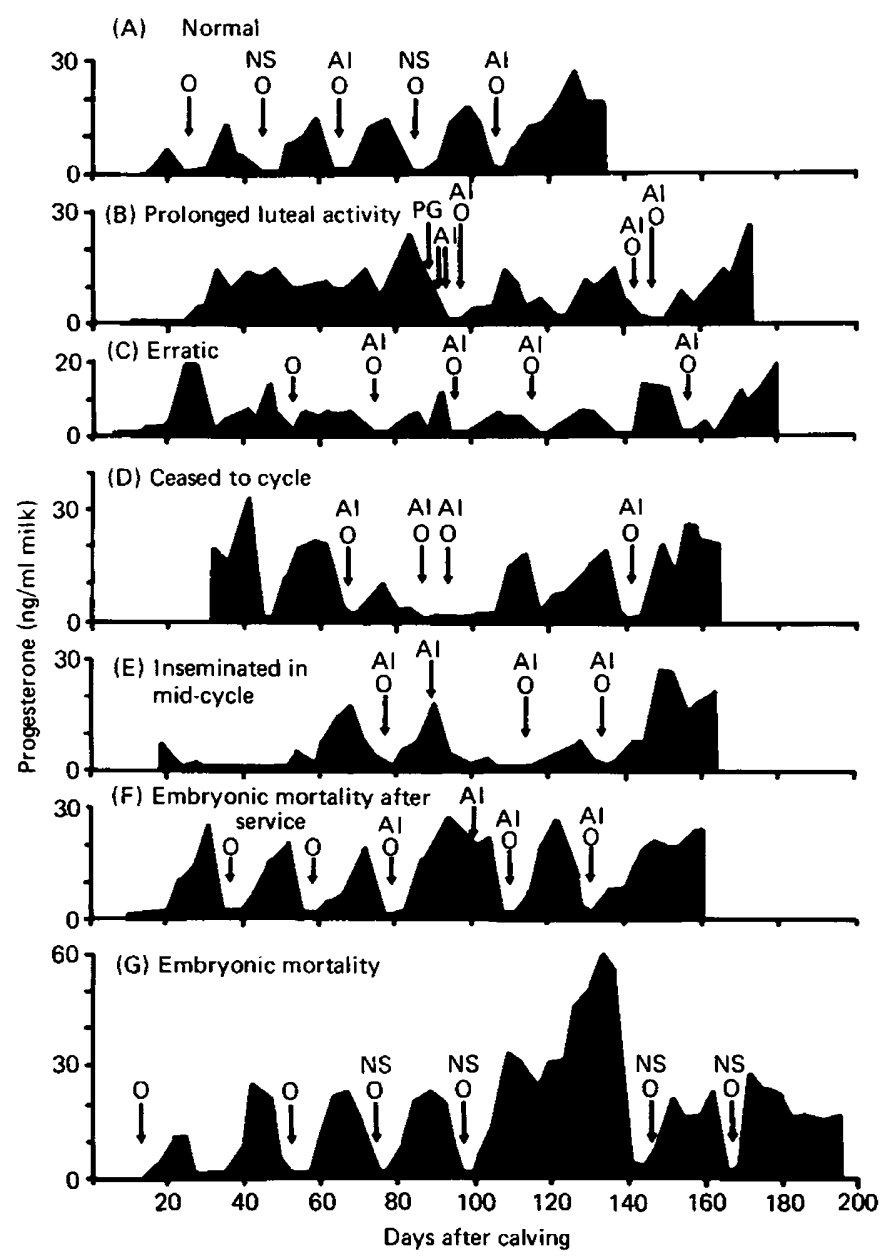

Text-fig. 3. Progesterone profiles to illustrate the different categories of repeat-breeder cows defined in Table $1 . \mathrm{O}=$ oestrus; $\mathrm{AI}=$ artificial insemination; $\mathrm{NS}=$ natural service; $\mathrm{PG}=$ single $\mathrm{i} . \mathrm{m}$. injection $0.5 \mathrm{mg}$ cloprostenol (ICI).

\section{The length of the post-partum interval}

The mean \pm s.e.m. interval between parturition and the resumption of ovarian cycles for 505 cows was $24 \cdot 1 \pm 0.63$ days. Animals were then classified according to lactation number and month of calving (Table 2). The mean post-partum interval increased after the 5th lactation. There was a noticeable seasonal effect with longer intervals occurring more commonly in cows calving between 
March and May. In the herds studied heifers generally calved in the early autumn and older cows tended to calve in the spring at the end of the main season. Lactation age and month of calving were not independent $\left(\chi_{99}^{2}=152 \cdot 2, P<0.005\right)$. To clarify these relationships a further analysis was performed and the results are shown in Table 3. The interaction between season and the interval to the start of cyclicity was highly significant even after age had been taken into account. However, if the intervals were first corrected for season the age effect just failed to achieve significance.

Table 2. Variations in the interval between parturition and the resumption of ovarian cycles* for $505+$ dairy cows according to lactation number and month of calving

\begin{tabular}{|c|c|c|c|c|c|c|c|c|c|c|c|c|}
\hline $\begin{array}{l}\text { Lactation no. } \\
\text { No. of cows } \\
\text { Days to start of } \\
\text { cycles } \\
\text { (mean } t \text { s.e.m ) }\end{array}$ & $\begin{array}{c}1 \\
139 \\
\\
24 \cdot 5 \\
\pm 1 \cdot 50\end{array}$ & $\begin{array}{c}2 \\
103 \\
\\
22 \cdot 4 \\
\pm 0 \cdot 90\end{array}$ & $\begin{array}{c}3 \\
85 \\
\\
22 \cdot 3 \\
\pm 1 \cdot 20\end{array}$ & $\begin{array}{c}4 \\
58 \\
\\
23 \cdot 4 \\
\pm 1 \cdot 10\end{array}$ & $\begin{array}{c}5 \\
48 \\
\\
22 \cdot 7 \\
\pm 1 \cdot 30\end{array}$ & $\begin{array}{c}6 \\
35 \\
\\
28 \cdot 3 \\
\pm 3 \cdot 45\end{array}$ & $\begin{array}{c}7 \\
18 \\
\\
29 \cdot 3 \\
\pm 4 \cdot 85\end{array}$ & $\begin{array}{c}8 \\
11 \\
39 \cdot 7 \\
\pm 4 \cdot 07\end{array}$ & $\begin{array}{r}9 \\
6 \\
41 \cdot 2 \\
\pm 4 \cdot 07\end{array}$ & $\begin{array}{r}10 \\
1 \\
20\end{array}$ & $\begin{array}{r}11 \\
1 \\
13\end{array}$ & \\
\hline $\begin{array}{l}\text { Month of calving } \\
\text { No. of cows } \\
\text { Days to start of }\end{array}$ & $\begin{array}{c}\text { Jan. } \\
25\end{array}$ & $\begin{array}{c}\text { Feb. } \\
9\end{array}$ & $\begin{array}{l}\text { March } \\
16\end{array}$ & $\underset{5}{\text { April }}$ & $\begin{array}{c}\text { May } \\
12\end{array}$ & $\begin{array}{c}\text { June } \\
10\end{array}$ & $\begin{array}{c}\text { July } \\
28\end{array}$ & $\begin{array}{l}\text { Aug. } \\
69\end{array}$ & $\begin{array}{l}\text { Sept. } \\
74\end{array}$ & $\begin{array}{l}\text { Oct. } \\
120\end{array}$ & $\begin{array}{l}\text { Nov. } \\
82\end{array}$ & Dec. \\
\hline $\begin{array}{l}\text { cycles } \\
\text { (mean } \pm \text { s.e.m.) }\end{array}$ & $\begin{array}{l}31 \cdot 3 \\
\pm 5.63\end{array}$ & $\begin{array}{l}20.3 \\
\pm 1.62\end{array}$ & $\begin{array}{l}38 \cdot 6 \\
\pm 6 \cdot 88\end{array}$ & $\begin{array}{l}52 \cdot 4 \\
\pm 15 \cdot 12\end{array}$ & $\begin{array}{l}38 \cdot 2 \\
\pm 6 \cdot 10\end{array}$ & $\begin{array}{l}23 \cdot 1 \\
\pm 2 \cdot 60\end{array}$ & $\begin{array}{l}20 \cdot 4 \\
\pm 1 \cdot 72\end{array}$ & $\begin{array}{c}25 \cdot 0 \\
\pm 1 \cdot 72\end{array}$ & $\begin{array}{l}22.7 \\
\pm 1.57\end{array}$ & $\begin{array}{c}19 \cdot 8 \\
\pm 0.96\end{array}$ & $\begin{array}{c}24 \cdot 8 \\
\pm 1 \cdot 50\end{array}$ & $\begin{array}{c}22.8 \\
\pm 0.94\end{array}$ \\
\hline
\end{tabular}

*Defined as the first milk progesterone measurement $>3 \mathrm{ng} / \mathrm{ml}$ which was followed by ovarian cycles.

$\dagger$ Milk samples were not obtained from 30 cows immediately after parturition and these animals were therefore omitted from the calculations.

Table 3. Effect of month of calving and lactation age on days from parturition to the start of progesterone secretion

\begin{tabular}{lrrrr}
\hline \multicolumn{1}{c}{ Source of variation } & d.f. & M.S. & F & $P$ \\
\hline Lactation age uncorrected for month of calving & 10 & 630.0 & 3.29 & $<0.01$ \\
Lactation age corrected for month of calving & 10 & 332.0 & 1.74 & $<0.1>0.05$ \\
Month of calving uncorrected for lactation age & 11 & $1229 \cdot 1$ & 6.43 & $<0 \cdot 01$ \\
Month of calving corrected for lactation age & 11 & $958 \cdot 2$ & 5.01 & $<0.01$ \\
Remainder (error) & 483 & $191 \cdot 2$ & & \\
Total & 504 & & & \\
\hline
\end{tabular}

The total milk yield per lactation was estimated from the weekly milk records for 258 cows which calved in the first year of study. There was no correlation between total yield and the interval between parturition and the start of ovarian cycles. Animals from one herd $(\mathrm{N}=147)$ which were studied in more detail showed no significant relationship between the post-partum interval and the yield at 4 or 8 weeks after calving.

The interval from calving to start of cyclicity was measured in two consecutive lactations for 115 cows, and was $24 \pm 1.4$ days at the first and $22 \pm 0.8$ days at the second lactation. Analysis of variance showed that there was significantly more variation between than within cows $(\mathrm{F}=2 \cdot 352$, $P<0.01)$. The intervals within cows were significantly correlated $(r=0.47, P<0.01)$.

\section{Group A}

In year 1 of the study (May 1976-April 1977) 6.8\% of cows had not started to cycle within 50 days of parturition. In the next 8 months (May 1977-December 1977) the lower incidence of $3.5 \%$ was probably due to the seasonal variation noted above. The milk progesterone profiles of 3 of these cows are illustrated in Text-fig. 4 (a, b, c). In the whole sample of 535 cows, a delayed start to ovarian cycles was found in $12(8.6 \%)$ of 140 first lactation cows compared with only $1.9 \%(6 / 320)$ of the 2 nd to 5 th lactation cows. The frequency increased in older animals and $13.3 \%(10 / 75)$ of those in their 6 th to 
11 th lactations were classified in this way. The total milk yield of Group A cows in Year $1(5424 \pm 410$ litres/lactation, $\mathrm{N}=15$ ) was not significantly different from that of normal cows (5203 \pm 92 litres/ lactation, $N=203$ ).

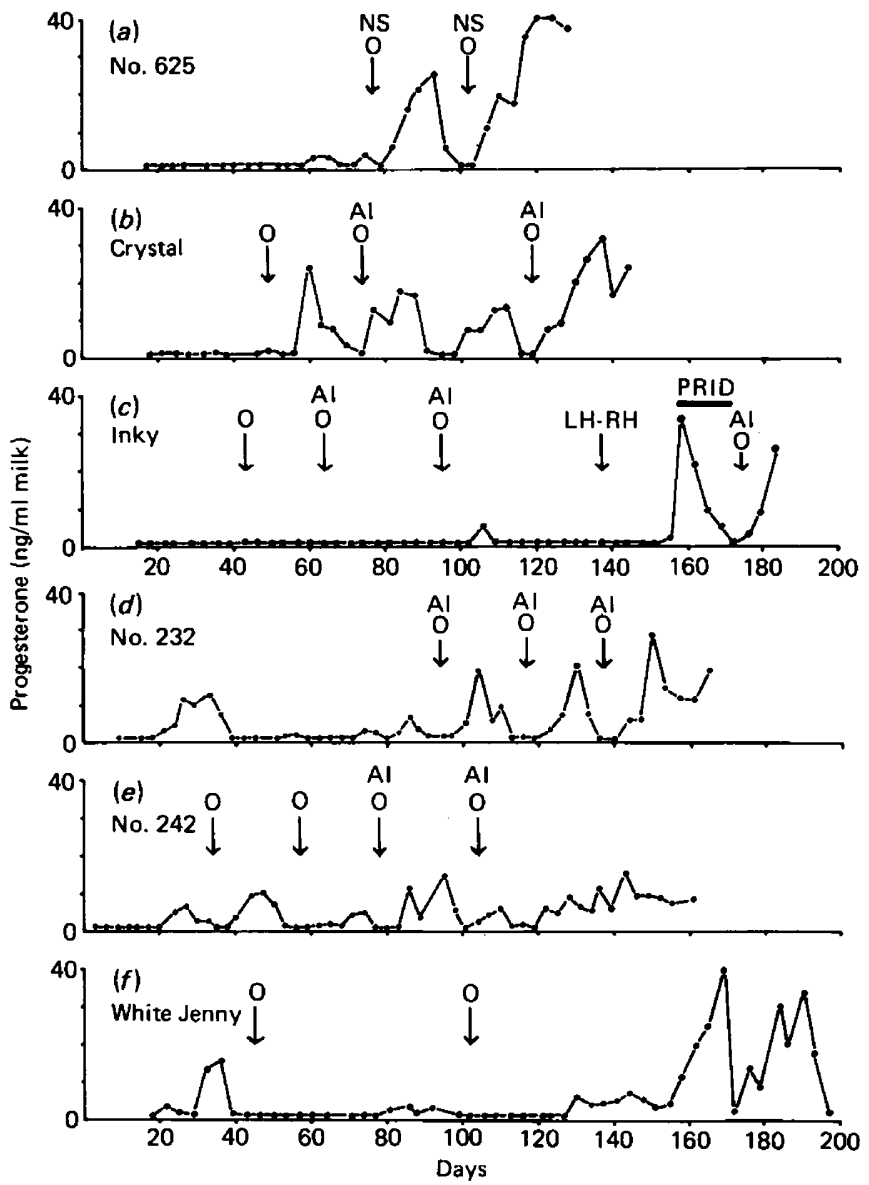

Text-fig. 4. Milk progesterone profiles of cows in Group A (a, b, c) and Group B (d, e,f) of study 2, showing the occurrence of very low progesterone levels. In Group A the progesterone levels remained low until at least $\mathbf{5 0}$ days after calving and such animals were therefore easy to diagnose as having delayed cycles. In Group B, the erratic occurrence of small progesterone rises interspersed with periods of low progesterone makes these cows difficult to recognize and treat. $\mathrm{O}=$ oestrus; $\mathrm{AI}=$ artificial insemination; $\mathrm{NS}=$ natural service; $\mathrm{LH}-\mathrm{RH}=$ single i.m. injection $0.5 \mathrm{mg} \mathrm{LH-RH}$; PRID = progesterone releasing intravaginal device inserted for 14 days.

The effect of treatment on the fertility of cows with a delayed start to cyclicity after parturition has been described elsewhere (Lamming \& Bulman, 1976; Bulman, McKibbin, Appleyard \& Lamming, 1978). Some of this information plus additional data are summarized in Table 4 . The treated animals required fewer services per conception and had a shorter calving to conception interval than the controls cows but the differences were not significant. For comparison, the mean \pm s.e.m. calving to conception interval in the four herds was $88.7 \pm 1.36$ days $(N=531)$ and the cows required $1.54 \pm 0.04$ services per conception.

\section{Group $\boldsymbol{B}$}

Ovarian cycles ceased for a period $>14$ days in $5.7 \%$ of the cows studied in Year 1 and in $4.7 \%$ of the cows studied in the following 8 months. Milk progesterone profiles from 3 Group $B$ cows are 
illustrated in Text-fig. 4 (d, e,f). Small rises in progesterone often occurred during the acyclic period, suggesting some luteal development but the levels did not reach those characteristically produced by a normal corpus luteum $(10-30 \mathrm{ng} / \mathrm{ml})$. Although animals placed in this cateogry had a higher mean milk yield ( $6227 \pm 380$ litres/lactation, $N=14)$ than normal cows $(5203 \pm 92$ litres/lactation, $N=203)$, this difference was not significant if the values were first corrected for the season of calving and the age of the cow.

Data from 16 untreated cows showed that the acyclicity began between 25 and 151 days after calving and lasted for an average of $39 \pm 4 \cdot 8$ days (range 21-91 days). Oestrus was often observed after the transient progesterone increases and as these were not necessarily followed by luteal development the animals frequently received several inseminations before conceiving. Cow 242 conceived to the insemination given at 104 days post partum and has since calved although the milk progesterone level was basal between 8 and 16 days after insemination (Text-fig. 4e).

There were fewer animals in the treated than the control groups because the irregular progesterone profiles made immediate diagnosis difficult. The results summarized in Table 4 show that treatment did not reduce the calving to conception interval in comparison with the control cows.

Table 4. The effect of treatment of delayed cyclic (Group A) and acylic (Group B) cows with a single i.m. injection of $0.5 \mathrm{mg} \mathrm{LH}-\mathrm{RH}$ or a progesterone-releasing intravaginal device (PRID) for 14 days

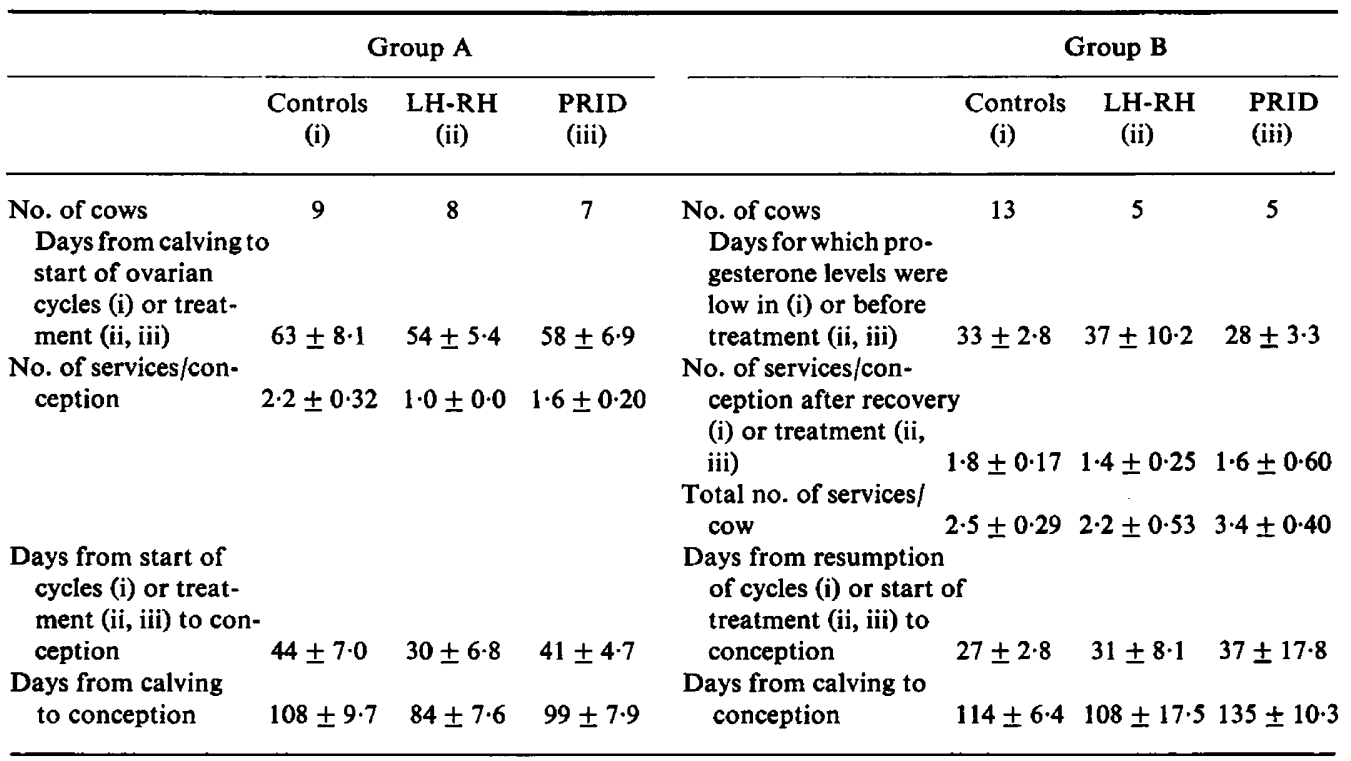

\section{Discussion}

\section{Progesterone levels and conception}

The milk progesterone concentrations before and after the first insemination did not differ markedly between cows which did or did not conceive. Our observations were based on milk rather than plasma measurements of progesterone. However, many authors have found that changes in the progesterone concentrations in the two media alter synchronously during the oestrous cycle and pregnancy (e.g. Ginther, Nuti, Wentworth \& Tyler, 1974; Hoffmann \& Hamburger, 1974; Dobson, Midmer \& Fitzpatrick, 1975; Lamming \& Bulman, 1976; Pope, Majzlik, Ball \& Leaver, 1976), and it therefore seems valid to extrapolate from one to the other.

Some infertile inseminations were accompanied by irregularities in the milk progesterone profile, but equally some cows conceived although their profiles differed considerably from the 'normal' pattern. These results contrast with the work of Rosenberg et al. (1977), who found that in summer infertile inseminations were preceded by a cycle in which the mean progesterone concentrations were 
significantly lower, and of Erb et al. (1976), who noted that cows which conceived had significantly higher progesterone concentrations from 6 days after insemination onwards. It is, therefore, still impossible to decide whether a deficiency of progesterone during the luteal phase preceding or following ovulation is a critical factor for conception. In women, the 'luteal phase defect', characterized by a short luteal phase with low plasma progesterone levels, is an accepted symptom of infertility. However, this condition occurs in only a small proportion of those patients already preselected because of their persistent infertility (Jones, 1976; Cooke, Lenton, Adams, Pearce, Fahmy \& Evans, 1977), and we believe that the studies of women and cows are not directly comparable. In the present study, divergence of milk progesterone profiles between pregnant and nonpregnant cows occurred at 13 days and this result is confirmed by those of another study which show that plasma progesterone levels in cows that conceive are higher from the mid-luteal phase onwards (W. Hansel, personal communication). Therefore if conception does not occur, the mechanism of luteolysis must be initiated before about Day 13. However, Betteridge, Eaglesome, Randall, Mitchell \& Sugden, (1978) have shown that embryo transfer as late as Day 17 to a non-inseminated recipient cow can result in normal pregnancy. These studies suggest that the early bovine conceptus can exert a positive lueotrophic influence.

\section{Repeat breeding}

The progesterone profiles of the repeat breeders were often irregular (Categories II, III and IV). No information is available about the levels of gonadotrophins and oestrogens in these animals but it is likely that they were suffering from a temporary endocrine imbalance resulting in ovulation failure, fertilization failure or early embryonic loss. Most eventually conceived as the pregnancy rate was $11 / 14$ after 4 or 5 inseminations. Nearly $20 \%$ of the repeat breeder cows were inseminated when their progesterone levels were high. Hoffmann, Gunzler, Hamburger \& Schmidt (1976) also reported a figure of $22 \%$ but Appleyard \& Cook (1976) found only 6/141 cows examined had luteal levels of progesterone at the time of insemination. In the current study about $50 \%$ of the apparently pregnant cows in Category VI which received additional inseminations later returned to oestrus. This is a problem which has been appreciated for some time. Salisbury \& VanDemark (1961) found that intrauterine insemination of pregnant cows nearly always resulted in abortion whereas intracervical insemination diminished the danger of interrupting the pregnancy. Between 3 and $10 \%$ of cows may show oestrus while pregnant (Salisbury \& VanDemark, 1961; Nalbandov, 1964) but a proportion of such unnecessary inseminations are probably attributable to mistakes in detection of oestrus by the herdsman. If the result of a previous insemination is in doubt, intracervical insemination should be used as advocated by VanDemark, Salisbury \& Boley (1952) and Salisbury \& VanDemark (1961).

Apparently normal progesterone profiles were present in $30 \%$ (Category I). Most of these were not examined per rectum so it is possible that the low conception rate was caused by abnormalities in the tract such as blocked oviducts or endometritis as described by Garden, Olds, Mochow \& Mutter (1968). However $12 / 14$ conceived eventually and $4 / 5$ had good fertility during the subsequent lactation so it is unlikely that the majority were suffering from serious anatomical defects.

By using progesterone profiles alone it is difficult to distinguish cows which fail to conceive from those in which embryonic mortality occurs. Therefore the criterion of at least $\mathbf{3 0}$ days between ovulatory periods by which cows were assessed as Category I (normal) and Category VII (embryonic mortality) was arbitrary. Most oestrous cycles are 18-24 days in length (Dziuk, 1973) but longer cycles can occur in cows which have not been inseminated (Bulman \& Lamming, 1977). An early pregnancy specific test would be of considerable assistance to further work.

The present studies show that there is a wide range of milk progesterone levels in cows which conceive and that repeat breeding can be due to several reasons only some of which can definitely be identified as defects of endocrine activity in the cow.

\section{Factors affecting acyclicity}

The data presented in Study 2 indicated that both the age of the cow and the season in which it calved apparently influenced the time taken to resume ovarian cycles following parturition. The seasonal effect was difficult to interpret as the majority of animals in this study were intended to calve 
in the autumn and winter. Any cows which had a prolonged calving to conception interval in one year would therefore be more likely to calve later in the following year and there was some indication that animals which had been slow to resume cycles on one occasion would be slow again in their subsequent lactation. It is, however, uncertain whether cows likely to have a delayed start to cyclicity tended to calve in the spring or some factor associated with spring calving led to a delay in the resumption of oestrous cycles. It is possible that both effects occurred.

Seasonal variations in fertility and a longer interval between calving and the first observed oestrus in the winter and spring have been noted by others (Chapman \& Casida, 1937; Carman, 1955; De Kruif, 1975; Boyd, 1977). Management conditions vary throughout the year and De Kruif (1977) found that the type of housing affected the proportion of cows in anoestrus, the incidence being highest if animals were tied in stalls with no freedom of movement. Nutrition may also be important as spring calving cows are likely to have lower reserves of body fat than those calving at other times of the year. However, Thibault et al. (1966) found that seasonal variations in fertility did not coincide with the changeover from winter feeding and suggested that photoperiod rather than nutrition was the important influencing factor. This point cannot be resolved from the evidence currently avaiable.

Although the tendency for the post-partum interval to vary with age was not statistically significant it was in agreement with previous reports showing that the interval to first oestrus was shortest for middle aged cows and increased for older animals (Morrow, Roberts \& McEntee, 1969; De Kruif, 1975). In most female mammals the reproductive capacity rises to a maximum in early maturity and then gradually declines. Erickson, Reynolds \& Murphree (1976) found that, in a population of aged infertile Hereford cows, $80 \%$ had an apparently adequate germ cell population but $83 \%$ showed some form of ovarian abnormality, including cystic corpora lutea and anovulatory ovaries. These age-related changes could result from an alteration in the output of hypothalamic or pituitary hormones or by an inability of the ovaries to respond appropriately.

Fielden, MacMillan \& Watson (1973) and De Kruif (1977) have reported a high incidence of anoestrus associated with inactive ovaries in primiparous cows and this finding was supported by the present study. It is possible that anoestrous in first lactation cows could also have a nutritional basis as such cows have probably not reached adult size and body reserves must be used for growth as well as milk production.

A correlation between milk yield and fertility has been shown by some workers (Carman, 1955; Menge, Mares, Tyler \& Casida, 1962; Spalding, Everett \& Foote, 1975) whereas others have failed to do so (Smith \& Legates, 1962; Everett, Armstrong \& Boyd, 1966). Cystic ovarian disease is also more common in high yielding cows (Morrow et al., 1969; Roberts, 1971). In the present study higher yields were not associated with a delayed start to cyclicity.

The treatment of dairy cows with LH-RH causes the release of LH (Schams, Hofer, Hoffmann, Ender \& Karg, 1973) and in the present experiment those acyclic animals in which the injection was followed by a rise in progesterone concentration resumed normal cyclicity. This contrasts with the results for suckling beef cows in which a second injection of $\mathrm{LH}-\mathrm{RH}$ was required after the transient rise in progesterone to initiate ovarian cycles (Webb, Lamming, Haynes, Hafs \& Mann, 1977).

It is possible that progesterone has a modulating effect on endogenous gonadotrophin secretion which may be necessary for the induction of cyclic ovarian function (Lamming, 1978). The LH-RH and PRID treatments both tended to reduce the calving to conception intervals of the cows with a delayed start to cyclicity. Although $75 \%$ of the animals which ceased to cycle showed an increase in milk progesterone concentrations following these treatments, conception did not occur any earlier in the treated cows. Approximately $80 \%$ of the dairy cows studied resumed ovarian cycles within 30 days of parturition and it appears likely that the remainder would benefit by treatment at an earlier stage (e.g. at 35 days post partum) than that used in the current study. Cows which do not begin to cycle can be readily identified from the milk progesterone profiles but those which cease to cycle are more difficult to diagnose and treatment will therefore be more difficult for such animals.

We thank the Milk Marketing Board of England and Wales for financial support; Mrs $\mathbf{H}$. Wilkinson for technical assistance; the farmers and veterinary surgeons for their co-operation; $\mathrm{Mr}$ 
H. L. Back for advice on statistical analysis; Hoechst Pharmaceuticals for LH-RH; Abbott Laboratories for PRIDs; Dr B. J. A. Furr for progesterone antiserum and Professor J. A. Laing for milk for use in the standard curve. D.C.B. was in receipt of a M.A.F.F. post-graduate studentship.

\section{References}

APpleyard, W.T. \& CoOK, B. (1976) The detection of oestrus in dairy cattle. Vet. Rec. 99, 253-256.

Betteridge, K.J., Eaglesome, M.D., Randall, G.C.B. Mitchell, D. \& Sugden, E.A. (1978) Maternal progesterone levels as evidence of luteotrophic or antiluteolytic effects of embryos transferred to heifers 12-17 days after oestrus. Theriogenology 9, No. 1, 86.

Bierschwal, C.J., Garverick, H.A., Martin, C.E., YoungQuist, R.S., CANTLEY, T.C. \& Brown, M.D. (1975) Clinical response of dairy cows with ovarian cysts to GnRI.J. Anim. Sci.41, 1660-1665.

Boyd, H. (1977) Anoestrus in cattle. Vet. Rec. 100, 150-153.

Bulman, D.C. \& Lamming, G.E. (1976) Radioimmunoassay of progesterone in milk for the diagnosis and treatment of subfertility in dairy cows. J. Endocr. $71,52 P$.

Bulman, D.C. \& Lamming,G.E. (1977) Cases of prolonged luteal activity in the non-pregnant dairy cow. Vet.Rec. 100, 550-552.

Bulman, D.C., McKibiin, P.E., Appleyard, W.T. \& LAMmING, G.F. (1978) Effect of a progesteronereleasing intravaginal device on the milk progesterone levels, vaginal flora, milk yield and fertility of cyclic and non-cyclic dairy cows. J. Reprod. Fert. 53, 289296.

Callahan, C.J., Erb, R.E., Surve, A.H. \& Randel, R.D. (1971) Variables influencing ovarian cycles in post-partum dairy cows. J. Anim. Sci. 33, 1053-1059.

CARMAN, G.M. (1955) Interrelations of milk production and breeding efficiency in dairy cows. J. Anim. Sci. 14, 753-759.

CASIDA, L.E. (1961) Present status of the repeat-breeder cow problem.J. Dairy Sci. 44, 2323-2329.

Chapman, A.B. \& Casida, L.E. (1937) Analysis of variation in the sexual cycle and some of its component phases with special reference to cattle. $J$. agric. Res. 54, 417-435

Cooxe, I.D., Lenton, E.A., Adams, M., Pearce, M.A., FaHmy, D. \& Evans, C.R. (1977) Some clinical aspects of pituitary-ovarian relationships in women with ovulatory failure. J. Reprod. Fert. 51, 203-213.

Darling, J.A.B. \& Harkness, R.A. (1973) A method for the group analysis of steroids in milk. Acta endocr., Copenh. 72, 391-400.

Darling, J.A.B., Laing, A.H. \& Harkness, R.A. (1974) A survey of the steroids in cows' milk. $J$. Endocr. 62, 291-297.

DE KRUIF, A. (1975) An investigation of the parameters which determine the fertility of a cattle population and some of the factors which influence these parameters. Tijdschr. Diergeneesk. 100, 1089-1098.

DE KRUIF, A. (1977) Gen onderzock van runderen in anoestrua. [Studies on cattle in anoestrus]. Tijdschr. Diergeneesk. 102, 247-253.
Dobson, H., Midmer, S.E. \& Fitzpatrick, R.J. (1975). Relationship between progesterone concentrations in milk and plasma during the bovine oestrous cycle. Vet. Rec. 96, 222-223.

DzIUK, P. (1973) Occurrence, control and induction of ovulation in pigs, sheep and cows. In Handbook of Physiology, Section 7: Endocrinology Vol. II; Female Reproductive System, Part I, pp. 143-152. Ed. R. O. Greep, American Physiology Society, Washington, D.C.

ErB, R.E., Garverick, H.A., Randel, R.D., Brown, B.L. \& Callahan, C.J. (1976) Profiles of reproductive hormones associated with fertile and non-fertile inseminations of dairy cows. Theriogenology 5 , 227-242.

ERICKSON, B.H., ReYNolds, R.A. \& MURPhRee, R.L. (1976) Ovarian characteristics and reproductive performance of the aged cow. Biol. Reprod. 15, 555-560.

Esslemont, R.J. (1974) Economic and husbandry aspects of the manifestation and detection of oestrus in cows. Part I. Economic aspects. $A D A S Q$. Rev. 12, 175-184.

Esslemont, R.J. \& Ellis, P.R. (1975) The Melbred dairy herd health recording scheme. A report on the economic, reproductive and husbandry changes in 22 herds over three seasons. University of Reading, Department of Agriculture and Horticulture, Study No. 21.

Everett, R.W., Armstrong, D.V. \& Boyd, L.J. (1966) Genetic relationship between production and breeding efficiency. J. Dairy Sci. 49, 879-886.

Fielden, E.D., Macmillan, K.L. \& Watson, J.D. (1973) The anoestrous syndrome in New Zealand dairy cattle. I. A preliminary investigation. $N . Z$. vet.J. 21, 77-81.

FURR, B.J.A. (1973) Radioimmunoassay of progesterone in peripheral plasma of the domestic fowl in various physiological states and in follicular venous plasma. Acta endocr., Copenh. 72, 89-100.

Gadsby, J.E., Heap, R.B., Henville, A.E. \& Laing, J.A. (1974) A semi-automated technique for the estimation of progesterone in cow's milk and its application to pregnancy diagnosis. J. Physiol., Lond. 242, 3P-5P.

Ginther, O.J., Nuti, L., Wentworth, B.C. \& Tyler, W.J. (1974) Progesterone concentration in milk and blood during pregnancy in cows. Proc. Soc. exp. Biol. Med. 146, 354-357.

Gonzalez-Padilla, E., Wiltbank, J.N. \& Niswender, G.D. (1975) Puberty in beef heifers. III. Induction of fertile estrus. J. Anim. Sci. 40, 1110-1118.

Graden, A.P., Olds, D., Mochow, C.R. \& Mutter, L.R. (1968) Causes of fertilization failure in repeat breeding cattle. J. Dairy Sci. 51, 778-781. 
Hansel, W., Concannon, P.W. \& Lukaszewska, J.H. (1973) Corpora lutea of the large domestic animals. Biol. Reprod. 8, 222-245.

HoffmanN, B. \& Hamburger, R. (1974) Determination of progesterone in milk by radioimmunoassay and its application for the diagnosis of bovine fertility. Acta endocr., Copenh., Suppl.184, 90.

HoffmanN, B., Gunzler, O., Hamburger, R. \& Schmid, W. (1976) Milk progesterone as a parameter for fertility control in cattle; methodological approaches and present status of application in Germany. Br. vet.J. 132, 449-476.

JoHNSON, A.D. \& ULBERG, L.C. (1967) Influence of exogenous progesterone on follicular cysts in dairy cattle. J. Dairy Sci. 50, 758-761.

Jonfs, G.S. (1976) The luteal phase defect. Fert. Steril. 27, 351-356.

KING, G.J., HuRnik, J.F. \& Robertson, H.A. (1976) Ovarian function and estrus in dairy cows during early lactation.J. Anim. Sci.42, 688-692.

KITtoK, R.J., BRITT, J.H. \& CoNVEY, E.M. (1973) Endocrine response after GnRH in luteal phase cows and cows with ovarian follicular cysts. J. Anim. Sci.37, 985-989.

LAMMING, G.E. (1978) Reproduction during lactation. In Control of Ovulation, pp. 335-353. Eds D. B. Crighton, N. B. Haynes, G. R. Foxcroft, \& G. E. Lamming. Butterworths, London.

LAmming, G.E. \& Bulman, D.C. (1976) The use of milk progesterone radioimmunoassay in the diagnosis and treatment of subfertility in dairy cows. Br. vet.J. 132, 507-517

LouCA, A. \& Legates, J.E. (1968) Production losses in cattle due to days open. J. Dairy Sci. 51, 573-583.

Menge, A.C., Mares, S.E., Tyler, W.J. \& Casida, L.E. (1962) Variation and association among post-partum reproduction and production characteristics in Holstein-Friesian cattle. J. Dairy Sci. 45, 233-241.

Morrow, D.A., Roberts, S.J. \& McENTEe, K. (1969) A review of post-partum ovarian activity and involution of the uterus and cervix in cattle. Cornell Vet. 59, $134-154$.

Nalbandov, A.V. (1964) Reproductive Physiology, 2nd edn. W. H. Freeman \& Co., San Francisco.

Nelder, J.A. (1974) Log linear models for contingeny tables: a generalisation of classical least squares. Appl. Statist. 23, 323-329.

Nelder, J.A. \& Wedderburn,R.W.M. (1972) Generalised linear models. Jl. R. Statist. Soc. 135, 370-384.
Pelissier, C.L. (1976) Dairy cattle breeding problems and their consequences. Theriogenology 6, 575-583.

Pope, G.S., Majzlk, I., Ball, P.J.H. \& Leaver, J.D. (1976) Use of progesterone concentration in plasma and milk in the diagnosis of pregnancy in domestic cattle. Br. vet.J. 132, 497-506.

RoBeRTS, S.J. (1971) Veterinary Obstetrics and Genital Diseases, pp. 423-424. Roberts, Ithaca, New York.

Rosenberg, M., Herz, Z., Davidson, M. \& Folman, Y. (1977) Seasonal variations in post-partum plasma progesterone levels and conception in primiparous and multiparous dairy cows. J. Reprod. Fert. 51, 363-367.

Salisbury, G.W. \& VANDEMark, N.L. (1961) Physiology of Reproduction and Artificial Insemination of Cattle, W. H. Freeman \& Co., San Francisco.

Schams, D., Hofer, F., HoffmanN, B., Ender, M.L. \& KARG, H. (1973) Effects of synthetic LH-RH treatment on bovine ovarian function during oestrous cycle and post-partum period. Acta endocr., Copenh., Suppl. 177, 296.

Schams, D., Schallenberger, G., HoffmanN, B. \& KaRG, H. (1977) The oestrous cycle of the cow: hormonal parameters and time relationships concerning oestrous ovulation and electrical resistance of the vaginal mucus. Acta endocr., Copenh. 86, 180-192.

Smith, J.W. \& Legates, J.E. (1962) Relation of days open and days dry to lactation milk and fat yields. $J$. Diary Sci.45, 1192-1198.

Spalding, R.W., EvereTt, R.W. \& Foote, R.H. (1975) Fertility in New York artificially inseminated Holstein herds in dairy herd improvement. J. Dairy Sci. 58, 718-723.

Thibault, C., Courot, M., Martinet, L., Mauleon. P., Du Mesnil Du Buisson, F., Ortovant, R., Pelletier, J. \& Signoret, J.P. (1966) Regulation of breeding season and estrous cycles by light and external stimuli in some mammals. J. Anim. Sci. 25, Suppl. pp. 119-139.

VanDemark, N.L., Salisbury, G.W. \& Boley, L.E. (1952) Pregnancy interruption and breeding techniques in the artificial insemination of cows. J. Dairy Sci. 35, 219-223.

Webb, R., Lamming, G.E., Haynes, N.B., Hafs, H.D. \& MANN, J.G. (1977) Response of cyclic and postpartum suckled cows to injections of synthetic LH-RH. J. Reprod. Fert. 50, 203-210.

Received 3 July 1978 